\title{
FREQUENCY OF Candida SPECIES IN A TERTIARY CARE HOSPITAL IN TRIANGULO MINEIRO, MINAS GERAIS STATE, BRAZIL
}

Ralciane de Paula MENEZES(1), Joseane Cristina FERREIRA(2), Walkiria Machado de SÁ(3), Tomaz de Aquino MOREIRA(3), Lucivânia Duarte Silva MALVINO(3),

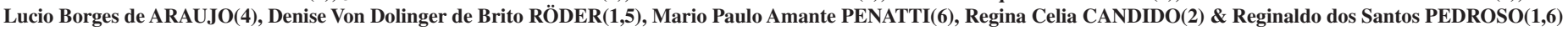

\begin{abstract}
SUMMARY
Infections by Candida species are a high-impact problem in public health due to their wide incidence in hospitalized patients. The goal of this study was to evaluate frequency, susceptibility to antifungals, and genetic polymorphism of Candida species isolated from clinical specimens of hospitalized patients. The Candida isolates included in this study were obtained from blood cultures, abdominal fluids, and central venous catheters (CVC) of hospitalized patients at the Clinical Hospital of the Federal University of Uberlândia during the period of July 2010 - June 2011. Susceptibility tests were conducted by the broth microdilution method. The RAPD-PCR tests used employed initiator oligonucleotides OPA09, OPB11, and OPE06. Of the 63 Candida isolates, 18 (28.5\%) were C. albicans, 20 (31.7\%) were C. parapsilosis complex species, 14 (22.2\%) C. tropicalis, four (6.4\%) C. glabrata, four (6.4\%) C. krusei, two (3.3\%) C. kefyr, and one (1.6\%) C. lusitaniae. In vitro resistance to amphotericin B was observed in $12.7 \%$ of isolates. In vitro resistance to azoles was not detected, except for $C$. krusei. The two primers, OPA09 and OPB11, were able to distinguish different species. Isolates of $C$. albicans and C. parapsilosis complex species presented six and five clusters, respectively, with the OPA09 marker by RAPD-PCR, showing the genetic variability of the isolates of those species. It was concluded that members of the C. parapsilosis complex were the most frequent species found, and most isolates were susceptible to the antifungals amphotericin B, flucozanole, and itraconazole. High genetic polymorphisms were observed for isolates of C. albicans and C. parapsilosis complex species, mainly with the OPA09 marker.
\end{abstract}

KEYWORDS: Antifungal susceptibility; Candida species; Candidemia; Genotyping.

\section{INTRODUCTION}

In recent decades, candidemia has increased significantly worldwide due to increased lifespans of immunosuppressed patients or transplant and

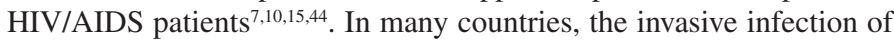
Candida yeast is a considerable public health problem, due to its severity, cause of increased hospital stays, cost, and contribution to high indexes of morbimortality. Some reports note that the mortality index caused by candidemia may reach $40-60 \%$ of hospital-admitted patients ${ }^{10,18,39,48}$.

Invasive candidiasis is related to several factors that compromise patient conditions, such as neutropenia, organ transplantations, previous colonization by Candida species, prolonged use of antibiotics, presence of catheters for nasogastric feeding, use of urinary or parenteral probes for hemodialysis or mechanical ventilation, neoplasia, immunosuppressive diseases, drugs, and gastrointestinal surgeries ${ }^{30}$.

For many years, C. albicans was regarded as the main cause of invasive fungal infections, but lately, non-C. albicans species have been reported to be predominant, especially in hospital environments ${ }^{28,39,44}$. According to some investigators, this is due to the selective pressure from the prophylactic use of fluconazole in patients at risk of developing invasive fungal infections ${ }^{18,41}$. Variable frequencies of different species of Candida are identified depending on the hospital complexity and/or geographic region ${ }^{13}$.

The choice of treatment for candidemia or invasive candidiasis is mainly based on two factors: Candida species and the condition of the host immune system. Depending on the protocol of the institution and the availability of antifungal agents, azoles (fluconazole, voriconazole, and posaconazole), polyene (amphotericin B), and/or echinocandins (caspofungin, anidulafungin, and micafungin) are used for the treatment. Echinocandins are recommended for prophylaxia and for the treatment of different groups of patients due to their efficacy and low toxicity in critical patients compared to other azoles and amphotericin $\mathrm{B}^{11,31,49}$.

Candidiasis epidemiology has been studied by genotypic analysis, which employs molecular tools with high discriminating power to

(1) Post-Graduation Program, FAMED, Federal University of Uberlândia (UFU), Uberlândia, Minas Gerais, Brazil.

(2) Faculty of Pharmaceutical Sciences of Ribeirao Preto, University of São Paulo (USP), Ribeirão Preto, São Paulo, Brazil

(3) Clinical Hospital of Uberlândia, UFU, Uberlândia, Minas Gerais, Brazil.

(4) Faculty of Mathematics, UFU, Uberlândia, Minas Gerais, Brazil.

(5) Institute of Biomedical Sciences, UFU, Uberlândia, Minas Gerais, Brazil.

(6) Technical School of Health, UFU, Uberlândia, Minas Gerais, Brazil.

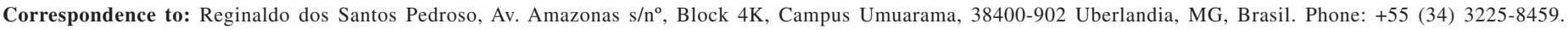

E-mail: rpedroso@estes.ufu.br 


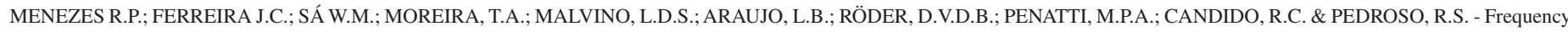
of Candida species in a tertiary care hospital in Triangulo Mineiro, Minas Gerais State, Brazil. Rev. Inst. Med. Trop. Sao Paulo, 57(3): 185-91, 2015.

distinguish different isolates, and thus allowing for improved accuracy in clinical and epidemiological studies ${ }^{29,34}$. These studies attempt to relate the genotypes of isolates with pathogenicity and epidemiology. Genotypes with varying degrees of heterogeneity were found in different anatomical sites among various population groups, including patients and healthy individuals, and in different geographical areas ${ }^{4,33,37}$.

The most commonly used molecular methods include polymorphism detection in the length of restriction fragments (RFLP) with hybridization (Southern blot) or amplification (AFLP), karyotyping in pulsed-field gel electrophoresis (PFGE), multi-locus sequence typing (MLST), and other techniques based on polymerase chain reaction (PCR) of random amplified polymorphic DNA (RAPD-PCR) 2,29,34.

Regional peculiarities and hospital complexity services may influence the predominance of Candida species. These emphasize the need for studies on epidemiology, prevalence, and resistance to antifungals. This study aims to evaluate the frequency, in addition to testing the susceptibility to antifungals as well as genetic polymorphisms, of Candida species isolated from samples of blood, CVC, and abdominal fluids of hospitalized patients in a tertiary hospital in the Triangulo Mineiro region, Minas Gerais State, Brazil.

\section{MATERIAL AND METHODS}

Isolates in the study: Candida samples included in the study were obtained from patients admitted to the Clinical Hospital of the Federal University of Uberlândia (UFU) in the city of Uberlândia located in the Triangulo Mineiro region, Minas Gerais State, Brazil, during the period of July 2010-June 2011. The isolates were from blood cultures, CVC, and abdominal fluids. Chromogenic agar (BD CHROMagar® Candida, France) and Sabouraud dextrose agar were used to isolate the yeasts, which were identified by classical methods ${ }^{21}$ and confirmed by the Auxacolor2 ${ }^{\circledR}$ system (Bio-Rad, France). Candida albicans and C. dubliniensis were differentiated by PCR utilizing specific primers, according to the technique described by ESTRADA-BARRAZA et al. ${ }^{14}$. Samples were stored in BHI-glycerol broth at $-20^{\circ} \mathrm{C}$. Experiments were conducted after sample activation and incubation at $35^{\circ} \mathrm{C}$ for $24-48 \mathrm{~h}$.

Antifungal susceptibility tests: The broth microdilution method described in document M27-A3, Clinical Laboratory Standard Institute $(\mathrm{CLSI})^{8}$, was used for the tests. Antifungals amphotericin B (Fungizon, Bristol Myers Squibb, Brazil), fluconazole (Pfizer, Sandwich, UK), and itraconazole (Janssen, Beerse, Belgium) were tested in culture plates of RPMI-1640 medium containing glutamine, without sodium bicarbonate, and buffered using pH-7.0 MOPS with glucose $(18 \mathrm{~g} / \mathrm{L})$. The final concentrations of the antifungal agents were $0.03-16 \mu \mathrm{g} / \mathrm{mL}$ for amphotericin B and itraconazole and $0.25-64 \mu \mathrm{g} / \mathrm{mL}$ for fluconazole. Briefly, yeasts were inoculated in Sabouraud dextrose agar and incubated at $35^{\circ} \mathrm{C}$ for $24 \mathrm{~h}$. Culture suspensions adjusted to $1-5 \times 10^{6} \mathrm{cells} / \mathrm{mL}$ were prepared in sterilized saline. Susceptibility tests were made in duplicates and the microdilution plates were incubated at $35{ }^{\circ} \mathrm{C}$ for $48 \mathrm{~h}$. Control strains were C. parapsilosis ATCC 22019 and C. krusei ATCC 6258. The minimum inhibitory concentration (MIC) was determined visually. For the azoles, MICs corresponded to the concentration inhibiting around $50 \%$ of growth for each microorganism compared to the control well (without antifungal); for amphotericin B, the MIC was the smaller drug concentration that inhibited $100 \%$ of yeast growth ${ }^{7}$. For azoles, breakpoints were as indicated in $\mathrm{CLSI}^{8,43}$, and, for amphotericin $\mathrm{B}$, due to lack of consensus, the values suggested by NGUYEN et al. ${ }^{29}$ were used.

Molecular typing: DNA extraction was performed according to the method of BOLANO et al. ${ }^{4}$. The RAPD-PCR tests were performed with initiator oligonucleotides OPA09 (5'GGGTAACGCC3'), OPB11 (5'GTAGACCCGT3'), and OPE06 (5'AAGACCCCTC3') (Invitrogen, São Paulo, Brazil). The reaction final volume was $25 \mu \mathrm{L}$ and contained $2 \mu \mathrm{L}$ DNA (60 ng/mL), $0.25 \mathrm{mmol}$ of each deoxynucleotide (dATP, dCTP, dTTP, and dGTP) (Invitrogen), $1 \mathrm{U}$ Taq polymerase (Invitrogen), $2.5 \mathrm{mM} \mathrm{MgCl}_{2}$, and $2.5 \mathrm{mM}$ initiator nucleotide. All amplifications were conducted in a thermalcycler (Eppendorf, Mastercycle Gradient, USA), consisting of an initial amplification cycle of four min at $92{ }^{\circ} \mathrm{C}$ followed by 40 cycles of $40 \mathrm{~s}$ at $92{ }^{\circ} \mathrm{C}, 40{ }^{\circ} \mathrm{C}$ for $1.5 \mathrm{~min}$, and $72{ }^{\circ} \mathrm{C}$ for two min, and finally followed by five min at $72^{\circ} \mathrm{C}$. Amplification fragments were separated by agarose gel (1.4\%) electrophoresis for three $\mathrm{h}$ at $80 \mathrm{~V}$ and $100 \mathrm{~mA}$. The gels were stained with ethidium bromide and visualized under UV light and the images were captured by a photo documentation system. Profiles for each sample were analyzed visually, and bands were classified as present (1) or absent (0). Genetic relationships (similarity coefficients) were calculated by the Jaccard coefficient equation $(S j)$ based on the position of fragments using the equation $S j=n_{A B} /\left(n_{A B}+a+b\right)$, where $n_{A B}$ is the number of bands shared by two samples: $a$, the number of exclusive bands for the first sample and $b$, for the second sample ${ }^{40}$. Values of $S j$ from 0.99-1.00 represent the same genotype, values from 0.800-0.99 represent clonally related samples (strongly similar but not identical), and values less than 0.800 indicate distinct samples. Dendrograms based on $S j$ values were generated for comparison by the unweighted pair group method with the arithmetical averages (UPGMA) method utilizing the multivariate statistical package program (MVSP).

Ethical committee: This study was approved by the Ethical Committee for Human Research of the Federal University of Uberlândia (UFU) under the number 317/10.

Statistical analysis: Qualitative variables were compared using the chi-square test, and the $\mathrm{G}$ test was used for quantitative results. In both tests, statistical significance was considered when $p<0.05$.

\section{RESULTS}

During the study period, 63 cultures of body fluids from individuals with suspected systemic candidiasis were positive for Candida spp., of which 47 were in blood, nine were in CVC, and seven in abdominal fluids, all obtained from 58 hospitalized patients at the Clinical Hospital of Federal University of Uberlândia. Thirty-four were from males and 24 from females. Ages of the patients ranged from one day to 94 years, with a mean age of 42 years. Most patients who developed systemic candidiasis and who had a positive culture were older than or equal to 21 years (Fig. 1).

Of the 63 Candida isolates, 18 (28.5\%) were identified as C. albicans and $45(72.5 \%)$ as non-C. albicans, distributed as follows: $20(31.7 \%) C$. parapsilosis complex species; $14(22.2 \%)$ C. tropicalis; four $(6.4 \%) C$. glabrata; four (6.4\%) C. krusei; two (3.3\%) C. kefyr; and one (1.6\%) C. lusitaniae. Candida dubliniensis was not identified by PCR. Except for C. albicans ( $p=0.050)$, the distribution of species between males and 


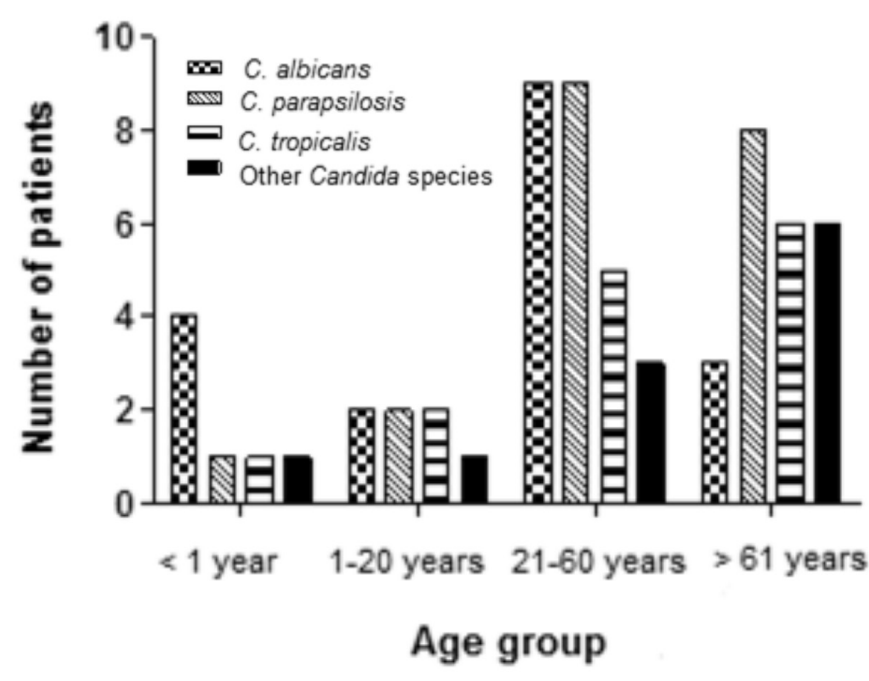

Note: Other species: C. krusei (4); C. glabrata (4); C. lusitaniae (1) and C. kefyr (2).

Fig. 1 - Distribution of Candida spp. according to age of hospitalized patients who developed systemic candidiasis during the period of July 2010-June 2011.

females was not statistically different for members of the $C$. parapsilosis complex $(p=0.057), C$. tropicalis $(p=0.4497)$, and other species $(p=$ 0.2008 ). However, there was a predominant tendency of $C$. albicans and C. parapsilosis complex species to affect males, once $55.5 \%$ and $65 \%$ of isolates, respectively, were obtained from male patients.

As shown in Table 1, the highest frequency of Candida isolates was from blood cultures $(55.6 \%)$, CVC (14.3\%), simultaneous isolations from blood-CVC (19\%) and abdominal fluids (11.1\%).

In vitro resistance to amphotericin $\mathrm{B}$ was observed in one isolate of $C$. albicans, in one of the C. parapsilosis complex, and in six other species - three $C$. krusei, two C. glabrata, and one $C$. kefyr - all with a MIC of $2 \mu \mathrm{g} / \mathrm{mL}$. None of the isolates, except C. krusei, was resistant to azoles in vitro.

Dose-dependent susceptibility to itraconazole was detected in one isolate of $C$. glabrata. Table 2 shows the MIC ranges of antifungals tested against Candida species.
Molecular analyses by RAPD-PCR with primers OPA09 and OPB11 produced different molecular profiles. Primer OPE06 did not amplify any genome fragments of the isolates included in the study. Analysis of the dendrogram generated from band profiles among isolates of the same species showed isolate groups with $S j=1.00$ (identical isolates with the same profile) and $S j<0.80$ (distinct samples). Table 3 shows frequencies of profiles generated with each primer for the most frequent species. Each profile relates isolates showing the same genotypes $(S j=1.00)$. Candida parapsilosis complex strains showed five (A-E) and four (A-D) profiles with OPA09 and OPB11, respectively.

Profile A of the each primer was composed of the higher number of isolates. Candida albicans isolates presented six and two profiles, respectively, with primers OPA09 and OPB11 (Table 3). Candida tropicalis isolates produced only one profile with OPA09 and two unrelated ones $(\mathrm{Sj}<0.8)$ with OPB11 (A-B) (Table 3). Two C. kefyr strains were demonstrated to be distinct strains with both primers $(S j<$ 0.80). Candida krusei showed two profiles with OPA09, each one with two isolates with similarity indexes that the indicated strains were clonally related $(0.99>S j>0.80)$; OPB11 produced only one profile, with $100 \%$ similarity among isolates. Candida glabrata produced two profiles with each one of the primers; OPA09 and OPB11 grouped three isolates in profile $\mathrm{A}$ and another isolate in profile $\mathrm{B}$, with $\mathrm{A}$ and $\mathrm{B}$ being unrelated $(S j<0.80)$ for both primers.

\section{DISCUSSION}

The predominance of Candida species non-C. albicans observed in this study confirms results reported in other studies from different Brazilian regions ${ }^{12,23,28}$. The $C$. parapsilosis complex occurred at the highest frequency compared to other species, including $C$. albicans. Observations from other Latin American countries and Tunisia show that C. parapsilosis-induced infections increased significantly in the past two decades $^{9,22}$. Candida albicans, C. tropicalis, and C. parapsilosis complex species are the most frequent species isolated in candidemia cases and constitute $82.5 \%$ as a whole of the isolates in this study and, in some other instances, represent more than $90 \%$ of etiologies ${ }^{30}$.

Candida parapsilosis has been reported as the second or third most frequent Candida species in candidemias ${ }^{9-12,15,24,27,35,38}$. In fact, in 2005, the $C$. parapsilosis complex was reclassified into three species: $C$. parapsilosis sensu stricto, C. orthopsilosis, and C. metapsilosis ${ }^{42}$. These three species may exhibit, according to some researchers, differences in

Table 1

Frequency of Candida species isolated from clinical specimens of patients from the Clinical Hospital of Federal University of Uberlândia who developed systemic candidiasis during the period of July 2010-June 2011

\begin{tabular}{|c|c|c|c|c|c|}
\hline Clinical specimens & C. parapsilosis & C. albicans & C. tropicalis & Others* & Total \\
\hline Blood & $11(17.4 \%)$ & $9(14.3 \%)$ & $10(15.9 \%)$ & $5(7.9 \%)$ & $35(55.6 \%)$ \\
\hline CVC & $6(9.5 \%)$ & $1(1.6 \%)$ & $1(1.6 \%)$ & $1(1.6 \%)$ & $9(14.3 \%)$ \\
\hline Blood + CVC & $3(4.8 \%)$ & $5(7.9 \%)$ & $2(3.2 \%)$ & $2(3.2 \%)$ & $12(19.0 \%)$ \\
\hline Abdominal fluids & $0(0.0 \%)$ & $3(4.8 \%)$ & $1(1.6 \%)$ & $3(4.8 \%)$ & $7(11.1 \%)$ \\
\hline Total isolates & $20(31.7 \%)$ & $18(28.6 \%)$ & $14(22.2 \%)$ & $11(17.4 \%)$ & $63(100 \%)$ \\
\hline
\end{tabular}

*Other species: C. krusei (4); C. glabrata (4); C. lusitaniae (1); and C. kefyr (2). CVC = central venous catheter. 


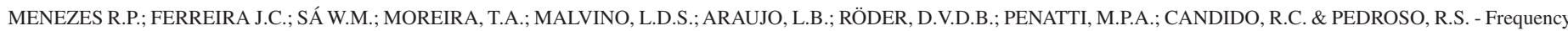
of Candida species in a tertiary care hospital in Triangulo Mineiro, Minas Gerais State, Brazil. Rev. Inst. Med. Trop. Sao Paulo, 57(3): 185-91, 2015.

Table 2

In-vitro susceptibility of Candida species to three antifungal agents

\begin{tabular}{|c|c|c|c|c|c|}
\hline \multirow{2}{*}{$\begin{array}{l}\text { Species } \\
\text { (n) }\end{array}$} & \multirow{2}{*}{ Antifungal agents } & \multicolumn{3}{|c|}{$\mathrm{MIC}(\mu \mathrm{g} / \mathrm{mL})$} & \multirow{2}{*}{$\begin{array}{c}\text { Resistant } \\
\mathrm{n}(\%)\end{array}$} \\
\hline & & Range & $\mathrm{MIC}_{50}$ & $\mathrm{MIC}_{90}$ & \\
\hline \multirow{3}{*}{$\begin{array}{l}\text { C. parapsilosis } \\
(20)\end{array}$} & Amphotericin B & $0.5-2.0$ & 1.0 & 1.0 & $1(5 \%)$ \\
\hline & Fluconazole & $0.125-1.0$ & 0.5 & 0.5 & 0 \\
\hline & Itraconazole & $0.03-0.125$ & 0.03 & 0.03 & 0 \\
\hline \multirow{3}{*}{$\begin{array}{l}\text { C. albicans } \\
\text { (18) }\end{array}$} & Amphotericin B & $0.5-2.0$ & 0.5 & 1.0 & $1(5.6 \%)$ \\
\hline & Fluconazole & $0.125-0.5$ & 0.125 & 0.5 & 0 \\
\hline & Itraconazole & 0.03 & 0.03 & 0.03 & 0 \\
\hline \multirow{3}{*}{$\begin{array}{l}\text { C. tropicalis } \\
\text { (14) }\end{array}$} & Amphotericin B & $0.5-1.0$ & 1.0 & 1.0 & 0 \\
\hline & Fluconazole & $0.125-0.5$ & 0.25 & 0.5 & 0 \\
\hline & Itraconazole & $0.03-0.06$ & 0.03 & 0.06 & 0 \\
\hline \multirow{3}{*}{$\begin{array}{l}\text { C. krusei } \\
\text { (4) }\end{array}$} & Amphotericin B & $1.0-2.0$ & - & - & $3(75 \%)$ \\
\hline & Fluconazole* & - & - & - & $4(100 \%)$ \\
\hline & Itraconazole & $0.03-0.12$ & - & - & 0 \\
\hline \multirow{3}{*}{$\begin{array}{l}\text { C. glabrata } \\
\text { (4) }\end{array}$} & Amphotericin B & $1.0-2.0$ & - & - & $2(50 \%)$ \\
\hline & Fluconazole & $0.5-4.0$ & - & - & 0 \\
\hline & Itraconazole & $0.25-0.3$ & - & - & 0 \\
\hline \multirow{3}{*}{$\begin{array}{l}\text { C. kefyr } \\
\text { (2) }\end{array}$} & Amphotericin B & $0.5-2.0$ & - & - & $1(50 \%)$ \\
\hline & Fluconazole & $0.125-0.5$ & - & - & 0 \\
\hline & Itraconazole & $0.06-0.125$ & - & - & 0 \\
\hline \multirow{3}{*}{$\begin{array}{l}\text { C. lusitaniae } \\
\text { (1) }\end{array}$} & Amphotericin B & 1 & - & - & 0 \\
\hline & Fluconazole & 0.25 & - & - & 0 \\
\hline & Itraconazole & 0.03 & - & - & 0 \\
\hline
\end{tabular}

${ }^{*}$ C. krusei is intrinsically resistant to fluconazole.

Table 3

Frequency of cluster profiles and isolates per cluster with primers OPA09 and OPB11

\begin{tabular}{lcccc}
\hline & \multicolumn{2}{c}{ OPA09 } & \multicolumn{2}{c}{ OPB11 } \\
\cline { 2 - 5 } Species(n) & $\begin{array}{c}\text { Molecular } \\
\text { profile* }\end{array}$ & $\begin{array}{c}\text { Frequency of } \\
\text { isolates }\end{array}$ & $\begin{array}{c}\text { Molecular } \\
\text { profile* }\end{array}$ & $\begin{array}{c}\text { Frequency of } \\
\text { isolates }\end{array}$ \\
\hline Candida & $\mathrm{A}$ & 10 & $\mathrm{~A}$ & 13 \\
parapsilosis & $\mathrm{B}$ & 3 & $\mathrm{~B}$ & 4 \\
(20) & $\mathrm{C}$ & 3 & $\mathrm{C}$ & 1 \\
& $\mathrm{D}$ & 3 & $\mathrm{D}$ & 1 \\
\hline & $\mathrm{E}$ & 1 & & 14 \\
Candida & $\mathrm{A}$ & 7 & $\mathrm{~A}$ & \\
albicans (18) & $\mathrm{B}$ & 4 & $\mathrm{~B}$ & 4 \\
& $\mathrm{D}$ & 4 & & \\
\hline Candida & $\mathrm{E}$ & 1 & & 13 \\
tropicalis & $\mathrm{F}$ & 1 & & \\
(14) & $\mathrm{A}$ & 14 & $\mathrm{~A}$ & \\
\hline
\end{tabular}

*A cluster was considered when it grouped isolates with $100 \%$ similarity. patterns of susceptibility to antifungal and biofilm production ${ }^{11}$. Of all the Candida isolates, they were detected in $55.6 \%$ of samples from blood cultures, $14.3 \%$ from CVC, $11.1 \%$ from abdominal fluids, and $19 \%$ from blood and CVC simultaneously. Positive results in blood cultures are considered the main indicators of invasive infections. Although cultures of samples obtained from other organic sites may be secondary in the diagnostics of hospital infection, these Candida isolates may have a predictive value for the occurrence of candidemias ${ }^{1,50}$.

Similar to what happened with bacteria, the indiscriminate use of antifungal drugs has stimulated the occurrence of fungi with decreased susceptibility or even in vitro resistance, especially among Candida species $^{6}$. In this study, the susceptibility of isolates in relation to fluconazole, itraconazole, and amphotericin $\mathrm{B}$, which were the antifungals used for treatment of invasive candidiasis in the service during the period studied, was analyzed. However, recent studies have pointed primarily to the use of echinocandins ${ }^{26,31,49}$. Most isolates were susceptible to the three antifungals evaluated. Candida krusei and C. glabrata are known to be resistant and less susceptible to fluconazole, respectively ${ }^{31,32,34,45,49}$. In vitro resistance of Candida species, notably non-C. albicans, to fluconazole has been reported in different hospital studies ${ }^{13,16,31,32,36,39}$. Itraconazole has been recently utilized in the treatment of candidemia in neutropenic patients because it is less toxic than amphotericin B, as well as having shown a similar 


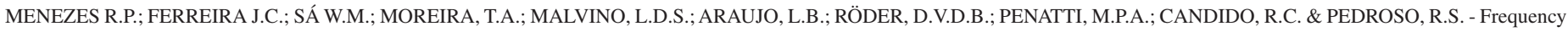
of Candida species in a tertiary care hospital in Triangulo Mineiro, Minas Gerais State, Brazil. Rev. Inst. Med. Trop. Sao Paulo, 57(3): 185-91, 2015.

effectiveness to that presented by other azoles ${ }^{17}$. One isolate $(25 \%)$ of C. glabrata showed a dose-dependent susceptibility to itraconazole, while NEUFELD et al. ${ }^{28}$ reported a dose-dependent susceptibility in only $3.4 \%$ of the isolates in their studies.

Resistance to amphotericin B has not been reported among isolates of different regions ${ }^{20,27,35,39}$. In this study, a MIC of $2 \mu \mathrm{g} / \mathrm{mL}$ was determined for some isolates, especially non- $C$. albicans ones, characterizing in vitro resistance. Data on the clinical outcomes of patients were not generated in this study, as in vitro results do not mean in vivo resistance, due to the fact that the cut-off point for amphotericin $\mathrm{B}$ is not established by the standardization committee due to technical difficulties related to the antifungal and culture media, as reported in the literature $e^{8,23,26,28,29}$. The results should be considered an alert and they should emphasize the importance of continuous surveillance to detect occasional isolates that are resistant to one or more antifungals. Future vigilance studies, including monitoring of patients, on antimicrobial resistance will show if these results were occasional or common occurrences.

The genetic variability of clinical isolates has been used to demonstrate cases of cross infection that occur in health care, but also to determine if the isolates of one anatomical site are identical to isolates from other sites of the same patient ${ }^{19,37}$.

In this study, the RAPD methodology was utilized in an attempt to reveal molecular variants of Candida spp. Based on the gel patterns and on the dendrograms obtained (data not shown), six profiles (A-F) were determined with primer OPA09 while OPB11 allowed only two (A-B) for isolates of $C$. albicans. Primer OPA09 had a higher discriminatory power especially for $C$. albicans and $C$. parapsilosis complex (Table 3 ). Neither of the two primers was able to discriminate isolates of $C$. tropicalis. Isolates of other species occurred in small numbers, so it is not possible to discuss this. Several studies have shown the discriminatory power of different primers and have suggested the use of multiple primers to improve the sensitivity of the results ${ }^{25,37,46,47}$.

This study identified a variety of strains in the patients involved, especially for isolates $C$. albicans and C. parapsilosis complex. However, it was not possible to show a cross infection at all. However, in 12 patients who had blood and CVC, positive cultures were isolated to the same species, and these exhibited the same genotype when blood and $\mathrm{CVC}$ isolates were compared. This might be evidence of hematological dissemination of this particular microorganism from the $\mathrm{CVC}$, but also blood-to-CVC. Identifying the source of infection is an important way to prevent infection. However, it suggests that prospective studies, including clinical data of patients and correlating these data with the microbiological characteristics of isolated samples may provide important insights for Candida spp. epidemiology in inpatients.

In conclusion, of the Candida species isolated during the study period, the most frequent were $C$. parapsilosis complex species followed by $C$. albicans and $C$. tropicalis. Most samples were susceptible to antifungals fluconazole, itraconazole, and amphotericin B. The genotypic markers seemed efficient at discriminating the isolates of $C$. albicans and $C$. parapsilosis; high genetic polymorphism was observed for isolates of $C$. albicans and $C$. parapsilosis complex species, mainly with the OPA09 marker.

\section{RESUMO}

\section{Frequência de espécies de Candida em hospital terciário do Triângulo Mineiro, Minas Gerais, Brasil}

As infecções causadas por espécies de Candida são problema de grande impacto para a saúde pública, devido à alta incidência em pacientes hospitalizados e como causa de mortalidade. O presente estudo teve como objetivo avaliar a frequência de Candida spp. isoladas de pacientes hospitalizados, assim como a sensibilidade aos antifúngicos e o polimorfismo genético por RAPD-PCR. Os microrganismos incluíram isolados de hemocultura, líquido abdominal e ponta de cateter venoso central de pacientes internados no Hospital de Clínicas da Universidade Federal de Uberlândia, região do Triângulo Mineiro, Minas Gerais, Brasil, no período de julho de 2010-junho de 2011. Os testes de sensibilidade aos antifúngicos foram realizados por microdiluição em caldo e na análise por RAPD-PCR foram utilizados os oligonucleotídeos OPA09, OPB11, e OPE06. Dos 63 isolados, 18 (28,5\%) foram C. albicans, 20 $(31,7 \%) C$. parapsilosis, $14(22,2 \%) C$. tropicalis, quatro $(6,4 \%) C$. glabrata, quatro (6,4\%) C. krusei, dois (3,3\%) C. kefyr, e um (1,6\%)C. lusitaniae. Resistência in-vitro à anfotericina B foi observada em $12,7 \%$ dos isolados. Não foi observada resistência in-vitro aos azólicos, exceto para os isolados de C. krusei. Os oligonucleotídeos OPA09 e OPB11 possibilitaram distinguir diferentes espécies. Isolados de C. albicans apresentaram seis clusters e o complexo C. parapsilosis, cinco clusters, com o iniciador OPA09, por RAPD-PCR, mostrando a variabilidade genética daquelas espécies. Conclui-se que o complexo $C$. parapsilosis foi a espécie mais frequente, e a maioria dos isolados foi sensível in vitro aos antifúngicos testados. Alto polimorfismo genético foi observado para os isolados de C. albicans e complexo C. parapsilosis, principalmente com o oligonucleotídeo OPA09.

\section{ACKNOWLEDGMENTS}

The authors are grateful to the National Research Council (CNPq) for the Scientific Initiation Fellowship awarded to R. P. Menezes, the Dean of the Undergraduate Federal University of Uberlândia (PROGRAD-UFU; edict 05/2010), to the Foundation for Research Support of Minas Gerais (FAPEMIG; process $\mathrm{n}^{\circ}$. APQ-00464-11), and to the Dean of Research and Graduate of the Federal University of Uberlândia (PROPP-UFU, Edict 04/2011) for financial support. They are also grateful to Lorraine Cristina Ribeiro Silva, Roterdan Martins Rosa, and Adriano Gonçalves Martins for technical assistance with some tests.

\section{CONFLICT OF INTEREST}

The authors have no conflict of interest to declare.

\section{REFERENCES}

1. Agvald-Ohman C, Klingspor L, Hjelmqvist H, Edlund C. Invasive candidiasis in long-term patients at a multidisciplinary intensive care unit: Candida colonization index, risk factors, treatment, and outcome. Scand J Infect Dis. 2008;40:145-53.

2. Bacelo KL, Costa KRC, Ferreira JC, Candido RC. Biotype stability of Candida albicans isolates after culture storage determined by randomly amplified polymorphic DNA and phenotypic methods. Mycoses. 2010;53:468-74.

3. Balajee SA, Sigler L, Brandt ME. DNA and the classical way: identification of medically important molds in the 21st century. Med Mycol. 2007;45:475-90. 
MENEZES R.P.; FERREIRA J.C.; SÁ W.M.; MOREIRA, T.A.; MALVINO, L.D.S.; ARAUJO, L.B.; RÖDER, D.V.D.B.; PENATTI, M.P.A.; CANDIDO, R.C. \& PEDROSO, R.S. - Frequency of Candida species in a tertiary care hospital in Triangulo Mineiro, Minas Gerais State, Brazil. Rev. Inst. Med. Trop. Sao Paulo, 57(3): 185-91, 2015.

4. Barros LM, Boriollo MFG, Alves ACBA, Klein MI, Gonçalves RB, Höfling JF. Genetic diversity and exoenzyme activities of Candida albicans and C. dubliniensis isolated from the oral cavity of Brazilian periodontal patients. Arch Oral Biol. 2008;53:1172-8.

5. Bolano A, Stinchi S, Preziosi R, Bistoni F, Allegrucci M, Baldelli F, et al. Rapid methods to extract DNA and RNA from Cryptococcus neoformans. FEMS Yeast Res. 2001;1:221-4.

6. Brion LP, Uko SE, Goldman DL. Risk of resistance associated with fluconazole prophylaxis: systematic review. J Infect. 2007;54:521-9.

7. Chang MR, Correia FP, Costa LC, Xavier PCN, Palhares DB, Taira DL, et al. Candida bloodstream infection: data from a teaching hospital in Mato Grosso do Sul, Brazil. Rev Inst Med Trop Sao Paulo. 2008;50:265-8.

8. Clinical and Laboratory Standards Institute (CLSI). Method for broth dilution antifungal susceptibility testing of yeasts: approved standard. $3^{\text {rd }}$ ed. Wayne: Clinical and Laboratory Standard Institute; 2008. (CLSI document M27-A3).

9. Colombo AL, Nucci M, Salomão R, Branchini ML, Richtmann R, Derossi A, et al. High rate of non-albicans candidemia in Brazilian tertiary care hospitals. Diagn Microbiol Infect Dis. 1999;34:281-6.

10. Colombo AL, Guimarães T. Epidemiologia das infecções hematogênicas por Candida spp. Rev Soc Bras Med Trop. 2003;36:599-607.

11. Colombo AL, Guimarães T, Camargo LF, Richtmann R, Queiroz-Telles FD, Salles $\mathrm{MJ}$, et al. Brazilian guidelines for the management of candidiasis: a joint meeting report of three medical societies: Brazilian Society of Infectious Diseases, Infectious Diseases Society of Paulista, and Brazilian Society of Tropical Medicine. Braz J Infect Dis. 2013;17:283-312.

12. Colombo AL, Guimarães T, Silva LR, Monfardini LPA, Cunha AK, Rady P, et al. Prospective observational study of candidemia in São Paulo, Brazil: incidence rate, epidemiology, and predictors of mortality. Infect Control Hosp Epidemiol. 2007;28:570-6

13. Colombo AL, Garnica M, Aranha Camargo LF, Da Cunha CA, Bandeira AC, Borghi D, et al. Candida glabrata: an emerging pathogen in Brazilian tertiary care hospitals. Med Mycol. 2013;51:39-44.

14. Estrada-Barraza D, Dávalos- Martínez A, Flores-Padilla L, Mendoza-Elias R, SánchezVargas LO. Comparación entre métodos convencionales CHROMagar Candida $\circledast$ y el método de la PCR para la identificación de especies de Candida en aislamientos clínicos. Rev Iberoam Micol. 2011;28:36-42.

15. Falagas ME, Roussous N, Vardakas KZ. Relative frequency of albicans and the various non-albicans Candida spp. among candidemia isolates from inpatients in various parts of the world: a systematic review. Int J Infect Dis. 2010;14:e954-e66.

16. Furlaneto MC, Rota JF, Quesada RM, Furlaneto-Maia L, Rodrigues R, Oda S, et al. Species distribution and in-vitro fluconazole susceptibility of clinical Candida isolates in a Brazilian tertiary-care hospital over a three-year period. Rev Soc Bras Med Trop. 2011;44:595-9.

17. Gafter-Gvili A, Vidal L, Goldberg E, Leibovici L, Paul M. Treatment of invasive candidal infections: systematic review and meta-analysis. Mayo Clin Proc. 2008;83:1011-21.

18. Giolo MP, Svidzinski TIE. Fisiopatogenia, epidemiologia e diagnóstico laboratorial da candidemia. J Bras Patol Med Lab. 2010;46:225-34.

19. Gurbuz M, Kaleli I. Molecular analysis of Candida albicans isolates from clinical specimens. Mycopathologia. 2010;169:261-7.

20. Junqueira JC, Vilela SF, Rossoni RD, Barbosa JO, Costa AC, Rasteiro VM, et al. Oral colonization by yeasts in HIV-positive patients in Brazil. Rev Inst Med Trop Sao Paulo. 2012;54:17-24.
21. Lacaz CS, Porto E, Martins JEC, Heins Vaccari EM, Melo NT. Tratado de micologia médica. São Paulo: Sarvier; 2002.

22. Makni F, Sellami A, Trabelsi H, Sellami H, Cheikh-Rouhou F, Neji S, et al. Evolution de la flore des levures isolées au CHU de Sfax, Tunisie. J Mycol Med. 2010;20:42-7.

23. Matta DA, Almeida LP, Machado AM, Azevedo AC, Kusano EJU, Travassos NF, $e$ al. Antifungal susceptibility of 1,000 Candida bloodstream isolates to five antifungal drugs: results of a multicenter study conducted in São Paulo, Brazil, 1995-2003. Diagn Microbiol Infect Dis. 2007;57:300-404.

24. Menezes EA, Vasconcelos Júnior AA, Cunha FA, Cunha MCSO, Braz BHL, Capelo LG, et al. Identificação molecular e suscetibilidade antifúngica de Candida parapsilosis isoladas no Ceará, Brasil. J Bras Patol Med Lab. 2012;48:415-20.

25. Miranda LN, van der Heijden IM, Costa SF, Sousa AP, Sienra RA, Gobara S, et al. Candida colonisation as a source for candidaemia. J Hosp Infect. 2009;72:9-16.

26. Moen MD, Lyseng-Williamson KA, Scott LJ. Liposomal amphotericin B: a review of its use as empirical therapy in febrile neutropenia and in the treatment of invasive fungal infections. Drugs. 2009;69:361-92.

27. Motta AL, Almeida GM, Almeida JN, Burattini MN, Rossi F. Candidemia epidemiology and susceptibility profile in the largest Brazilian teaching hospital complex. Braz J Infect Dis. 2010;14:441-8.

28. Neufeld PM, Santos LH, Ribeiro MD, Silva MF, Rocha ACM, Silva M, et al. Prevalência e susceptibilidade in-vitro a itraconazol e anfotericida B de isolados clínicos de Candida. Rev Bras Anal Clin. 2009;41:119-25.

29. Nguyen MH, Clancy CJ, Yu VL, Yu YC, Morris AJ, Snydam DR, et al. Do in-vitro susceptibility data predict microbiologic response to amphotericin B? Results of a prospective study of patients with Candida fungemia. J Infect Dis. 1998;177:425-30.

30. Nucci M, Queiroz-Telles F, Tobón AM, Restrepo A, Colombo AL. Epidemiology of opportunistic fungal infections in Latin America. Clin Infect Dis. 2010;51:561-70.

31. Pappas PG, Kauffman CA, Andes D, Benjamin DK Jr, Calandra TF, Edwards JE Jr, et al. Clinical practice guidelines for the management of candidiasis: 2009 update by the Infectious Diseases Society of America. Clin Infect Dis. 2009;48:503-35.

32. Pereira JM, Paiva JA. Tratamento da candidíase invasiva no doente crítico. Rev Port Med Int. 2010;17:23-30.

33. Pfaller MA, Cabezudo I, Hollis R, Huston B, Wenzel RP. The use of biotyping and DNA fingerprinting in typing Candida albicans from hospitalized patients. Diagn Microbiol Infect Dis. 1990;13:481-9.

34. Pfaller MA, Diekema DJ, Rinaldi MG, Barnes R, Hu B, Veselov AV. Results from the ARTEMIS DISK global antifungal surveillance study: a 6.5-year analysis of susceptibilities of Candida and other yeast species to fluconazole and voriconazole by standardized disk diffusion testing. J Clin Microbiol. 2005;43:5848-59.

35. Pfaller MA, Diekema DJ. Epidemiology of invasive candidiasis: a persistent public health problem. Clin Microbiol Rev. 2007;20:133-63.

36. Pfaller MA, Messer SA, Moet GJ, Jones RN, Castanheira M. Candida bloodstream infections: comparison of species distribution and resistance to echinocandin and azole antifungal agents in Intensive Care Unit (ICU) and non-ICU settings in the SENTRY Antimicrobial Surveillance Program (2008-2009). Int J Antimicrob Agents. 2011;38:65-9.

37. Pinto PM, Resende MA, Koga-Ito CY, Tendler M. Genetic variability analysis among clinical Candida spp. isolates using random amplified polymorphic DNA. Mem Inst Oswaldo Cruz. 2004;99:147-52

38. Pires RH, Santos JM, Zaia JE, Martins CHG, Mendes-Giannini MJS. Candida parapsilosis complex water isolates from a hemodialysis unit: biofilm production and in-vitro evaluation of the use of clinical antifungals. Mem Inst Oswaldo Cruz. 2011:106:646-54. 


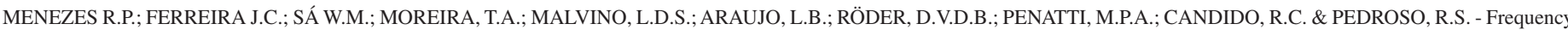
of Candida species in a tertiary care hospital in Triangulo Mineiro, Minas Gerais State, Brazil. Rev. Inst. Med. Trop. Sao Paulo, 57(3): 185-91, 2015.

39. Sellami A, Sellami H, Neji S, Makni F, Abbes S, Cheikhrouhou F, et al. Antifungal susceptibility of bloodstream Candida isolates in Sfax Hospital,Tunisia. Mycopathologia. 2011;171:417-22.

40. Soll DR. The ins and outs of DNA fingerprinting the infections fungi. Clin Microbiol Rev. 2000;13:332-70

41. Talarmin JP, Boutoille D, Tattevin $\mathrm{P}$, Dargère $\mathrm{S}$, Weinbreck $\mathrm{P}$, Ansart $\mathrm{S}$, et al. Epidémiologie des candidérmies; étude observationnelle prospective d'un an dans l'Ouest de la France. Med Mal Infect. 2009;39:877-85.

42. Tavanti A, Davidson AD, Gow NAR, Maiden MCJ, Odds FC. Candida orthopsilosis and Candida metapsilosis spp. nov. to replace Candida parapsilosis groups II and III. J Clin Microbiol. 2005;43:284-92.

43. The European Committee on Antimicrobial Susceptibility Testing, Subcommittee on Antifungal Susceptibility Testing (EUCAST-AFST). EUCAST technical note on fluconazole. Clin Microbiol Infect. 2008;14:193-5.

44. Tortorano AM, Peman J, Bernhardt H, Klingspor L, Kibbler CC, Faure O, et al. Epidemiology of candidaemia in Europe: results of a 28-month European Confederation of Medical Mycology (ECMM) hospital-based surveillance study. Eur J Clin Microbiol Infect Dis. 2004;23:317-22.
45. Tortorano AM, Kibbler C, Peman J, Bernhardt H, Klingspor L, Grillot R. Candidaemia in Europe: epidemiology and resistance. Int J Antimicrob Agents. 2006;27:359-66.

46. Trost A, Graf B, Eucker J, Sezer O, Possinger K, Göbel UB, et al. Identification of clinically relevant yeasts by PCR/RFLP. J Microbiol Methods. 2004;56:201-11.

47. Valerio HM, Weibert-Oliveira RCB, Resende MA. Differentiation of Candida species obtained from nosocomial candidemia using RAPD-PCR technique. Rev Soc Bras Med Trop. 2006;39:174-8

48. Viudes A, Permán J, Cantón E, Ubeda P, López-Ribot JL, Gobernado M. Candidemia at a tertiary care hospital: epidemiology, treatment, clinical outcome, and risk factors for death. Eur J Microbiol Infect Dis. 2002;21:767-74.

49. Walsh TJ, Gamaletsou MN. Treatment of fungal disease in the setting of neutropenia. Hematology Am Soc Hematol Educ Program. 2013;2013:423-7.

50. Wang JL, Chang SC, Hsueh PR, Chen YC. Species distribution and fluconazole susceptibility of Candida clinical isolates in a medical center in 2002. J Microbio Immunol Infect. 2004;37:236-41

Received: 3 March 2014

Accepted: 5 August 2014 